\title{
The influence of the driving speed on the exhaust emissions
}

The aim of the study is to verify the thesis about the influence of the vehicle speed on the exhaust emissions. The influence of the speed on the fuel consumption is quite easily measurable and generally possible to identify, while determining the emissions of harmful substances requires specialized research equipment. The analysis is important from the point of view of the vehicle operation. The paper presents the results of the road tests of a car fitted with a diesel engine. It contains the results of measurements of the concentration of the exhaust components. In the measurements, PEMS portable equipment was used. The study was conducted under actual traffic conditions (motorway driving) on a selected portion of the A2 motorway, located near Poznan.

Key words: road tests, exhaust emissions, vehicle speed

\section{Wpływ prędkości jazdy samochodem na emisję spalin}

W artykule przedstawiono wyniki badań, których celem było zweryfikowanie tezy o wpływie prędkości jazdy samochodem na emisję spalin. Wpływ prędkości jazdy na przebiegowe zużycie paliwa jest łatwo mierzalny i powszechnie możliwy do określenia, natomiast w celu określenia emisji substancji szkodliwych należy postużyć się specjalistyczna aparatura badawcza. Przeprowadzono analizę, która jest istotna z punktu widzenia ekologii eksploatacji pojazdów samochodowych. Zaprezentowano wyniki badań drogowych samochodu osobowego napędzanego silnikiem o zaptonie samoczynnym. Artykut zawiera także wyniki pomiarów stężenia podstawowych zwiazków szkodliwych emitowanych ze spalinami przez silnik tego pojazdu. W pomiarach wykorzystano mobilna aparaturę do badań toksyczności spalin typu PEMS. Badania przeprowadzono w rzeczywistych warunkach ruchu samochodu (jazda autostradowa) na wybranym fragmencie autostrady A2, zlokalizowanym w rejonach Poznania.

Słowa kluczowe: badania drogowe, emisja spalin, prędkość jazdy

\section{Introduction}

Each moving vehicle is subject to a variety of forces, including all kinds of resistances (all the forces that oppose the driving force of a vehicle). The resistance force - motion resistance of a vehicle occurs under all operating conditions (Fig. 1). Not all of them, however occur at the same time. The number and kind of the occurring forces depend on the conditions under which the motor vehicle is operated [4]. When driving a vehicle at high speeds the dominating share in the resistance has the aerodynamic resistance that is directly proportional to the square of the vehicle speed.

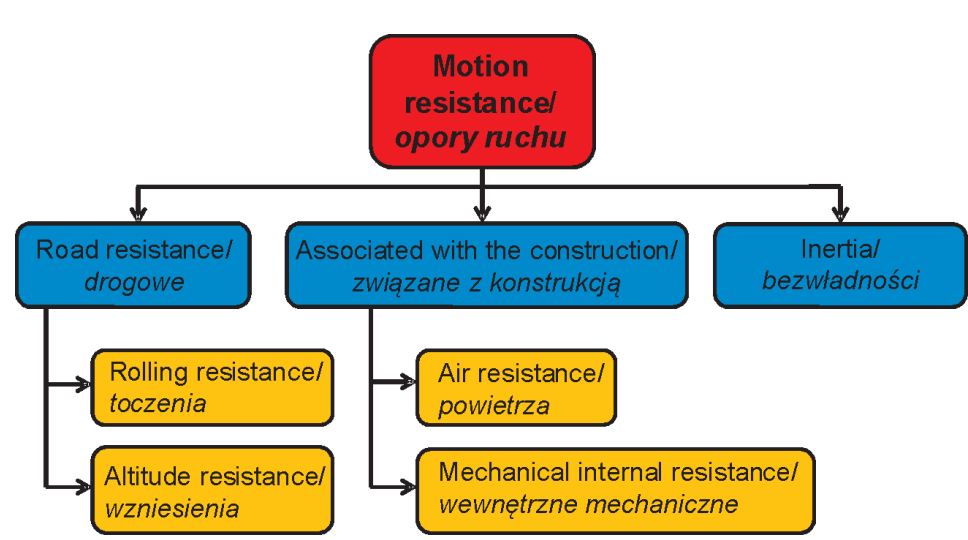

Fig. 1. Types of vehicle motion resistance [8] Rys. 1. Rodzaje oporów ruchu pojazdu [8]

\section{Wprowadzenie}

Każdy poruszający się po drodze pojazd podlega oddziaływaniu wielu sił, w tym różnego rodzaju sił oporu (są to te wszystkie siły, które przeciwstawiają się sile napędowej pojazdu). Siły oporu - opory ruchu pojazdu występują w każdych warunkach eksploatacyjnych (rys. 1). Nie wszystkie jednak występują jednocześnie. Liczba i rodzaj występujących sił oporu zależy od aktualnych warunków, w jakich użytkuje się pojazd silnikowy [4]. Przy jeździe samochodem $\mathrm{z}$ dużymi prędkościami dominujący udział w oporach ruchu ma opór aerodynamiczny, który jest wprost proporcjonalny do powierzchni czołowej samochodu oraz do kwadratu prędkości jazdy.

W artykule przedstawiono zagadnienia emisji związków gazowych, takich jak: $\mathrm{CO}, \mathrm{CO}_{2}, \mathrm{HC}, \mathrm{NO}_{\mathrm{x}}$ w odniesieniu do pojazdów zasilanych silnikami o zapłonie samoczynnym, $w$ aspekcie kształtowania maksymalnej prędkości jazdy samochodem. Duża wartość prędkości jazdy odpowiada bowiem w znacznym stopniu za wyemitowane związki szkodliwe [1].

Celem badań było znalezienie rozwiazań zagadnienia wzrostu emisji związków szkodliwych spalin wraz ze wzrostem prędkości jazdy o kilkadziesiąt kilometrów na godzinę. W efekcie podjętej analizy uzyskano wyniki dotyczące obciążeń środowiskowych dla różnej prędkości jazdy samochodem. 
The paper presents problems of the emission of the exhaust components $\left(\mathrm{CO}, \mathrm{CO}_{2}, \mathrm{HC}, \mathrm{NO}_{\mathrm{x}}\right)$ from diesel vehicles in relation to the maximum vehicle speed. High vehicle speed significantly impacts the exhaust emissions [1].

The aim of the investigations is to find the solution to the problem of the increase in the exhaust emissions with the increase of the vehicle speed. Following the analysis, results were obtained related to the environmental impacts for different vehicle speeds.

\section{Research methodology}

\subsection{Research object}

The road tests were performed on a PC type (Passenger Car) light-duty vehicle. The object of the investigations was a passenger car fitted with a four-cylinder diesel engine of the displacement of $1.9 \mathrm{dm}^{3}$ (Fig. 2, Tab. 1). The engine was fitted with a Diesel Oxidation Catalyst (DOC). Diesel Particulate Filter (DPF) was not installed. The vehicle drivetrain included a 5-speed transmission.

\section{Metodyka badań}

\subsection{Obiekt badań}

Badaniom w rzeczywistych warunkach eksploatacji poddano pojazd lekki typu PC (Passenger Car). Obiektem badań był samochód osobowy typu kombi wyposażony w 4-cylindrowy silnik o zapłonie samoczynnym o objętości skokowej 1,9 $\mathrm{dm}^{3}$ (rys. 2, tab. 1). Jednostka napędowa badanego samochodu była wyposażona tylko w utleniający reaktor katalityczny DOC (Diesel Oxidation Catalyst), natomiast nie był zainstalowany filtr cząstek stałych typu DPF (Diesel Particulate Filter). W skład układu napędowego pojazdu wchodziła również 5-biegowa skrzynia przekładniowa.

\subsection{Aparatura badawcza i warunki przeprowadzania pomiarów}

Pomiarów stężenia składników gazowych spalin badanego samochodu osobowego dokonano z wykorzystaniem mobilnej aparatury typu PEMS (Portable Emission Measurement System). Tego rodzaju aparatura naukowo-badawcza umożliwia wykonanie pomiarów zanieczyszczeń w spali-

Table 1. Characteristics of the vehicle used in tests

Tabela 1. Charakterystyka samochodu wykorzystanego do badań

\begin{tabular}{|l|c|c|}
\hline Technical parameters/parametry techniczne & $\begin{array}{c}\text { Unit/ } \\
\text { jednostka }\end{array}$ & Value/wartość \\
\hline Engine - type of ignition/silnik - rodzaj zapłonu & - & Diesel/ZS \\
\hline $\begin{array}{l}\text { Engine - cylinder number and arrangement/silnik-uktad i liczba } \\
\text { cylindrów }\end{array}$ & - & R4 \\
\hline Engine displacement/objętość skokowa silnika & $\mathrm{cm}^{3}$ & turbocharger/turbosprężarka \\
\hline Type of supercharging/rodzaj doładowania & - & $66 / 90$ \\
\hline Maximum power output/moc maksymalna & $\mathrm{kW} / \mathrm{KM}$ & 210 \\
\hline Maximum torque/maksymalny moment obrotowy & $\mathrm{N} \cdot \mathrm{m}$ & Diesel Oxidation Catalyst/utleniajacy reaktor \\
\hline Aftertreatment system/układ oczyszczania spalin & - & katalityczny \\
\hline Vehicle weight/masa pojazdu & & 1300 \\
\hline Vehicle mileage/przebieg pojazdu & $\mathrm{kg}$ & 210 000 \\
\hline Type/typ & $\mathrm{km}$ & Station wagon/kombi \\
\hline Year of manufacture/rok produkcji & - & 1998 \\
\hline
\end{tabular}
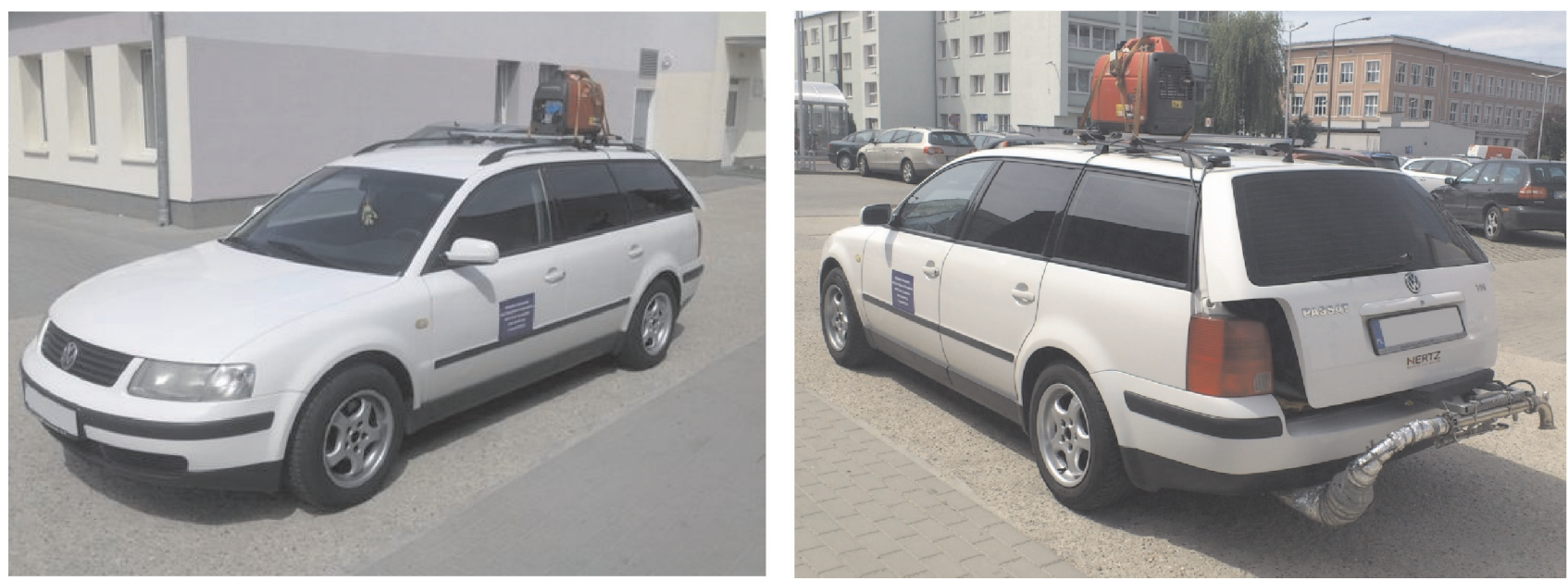

Fig. 2. The research object prepared for the road tests

Rys. 2. Obiekt badań przygotowany do pomiarów drogowych 


\subsection{Measurement equipment and conditions}

The measurements of the individual exhaust components were performed with the use of a portable exhaust emission measurement system (PEMS). This type of equipment can measure the exhaust emission under actual traffic conditions $\left(\mathrm{CO}, \mathrm{CO}_{2}, \mathrm{HC}, \mathrm{NO}_{\mathrm{x}}\right)$. The measurement range of the equipment allows a wide scope of application. The measurement system provides the emission data in real time, which provides quick research results. Currently, it is being proposed to incorporate the PEMS system into the European legislation actions, particularly for gaseous exhaust components - this issue is currently considered for heavy-duty vehicles only [2, 5-7].

The manufacturer of the SEMTECH-DS, a portable measurement analyzer is Sensors Inc. (Sensors EMission TECHnology; Fig. 3). The components of the described equipment are mainly analyzers dedicated for the individual exhaust components: NDIR (Non-Dispersive Infrared), NDUV (Non-Dispersive Ultraviolet) and FID (Flame Ionization Detector). Some other components of the SEMTECH-DS device include [3, 9]:

- exhaust gas mass flow meter for variable engine operating conditions of variable diameter depending on the engine displacement,

- data recording module pulling data from the vehicle OBD (On-Board Diagnostics) system - determines the driving conditions and engine operating parameters,

- a GPS module.

Aside from the exhaust components, the said portable PEMS equipment also measures the mass flow of the exhaust

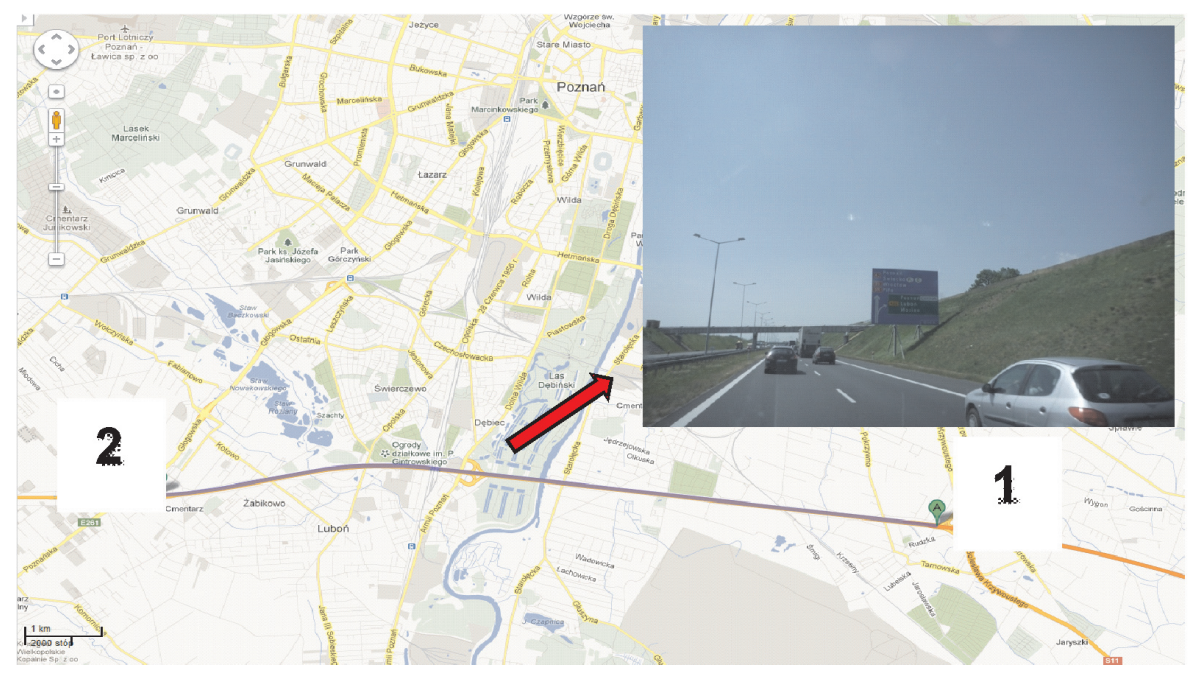

Fig. 4. Test route - a part of the A2 motorway near Poznan Rys. 4. Odcinek testowy - fragment autostrady A2 w rejonach Poznania nach w warunkach emisji drogowej - pomiar emisji $\mathrm{CO}$, $\mathrm{CO}_{2}, \mathrm{HC}, \mathrm{NO}_{\mathrm{x}}$. Zakresy pomiarowe aparatury umożliwiają zastosowanie jej w szerokim zakresie. Ponadto charakteryzuje się ona uzyskaniem wyniku pomiaru emisji wszystkich szkodliwych składników spalin w sposób natychmiastowy, co pozwala na szybkie wyciąganie wniosków z prowadzonych badań. Obecnie postuluje się wprowadzenie pomiarów systemami PEMS do europejskich działań legislacyjnych, szczególnie w zakresie pomiarów emisji składników gazowych - jednakże zagadnienie to rozpatrywane jest obecnie dla pojazdów ciężarowych [2, 5-7].

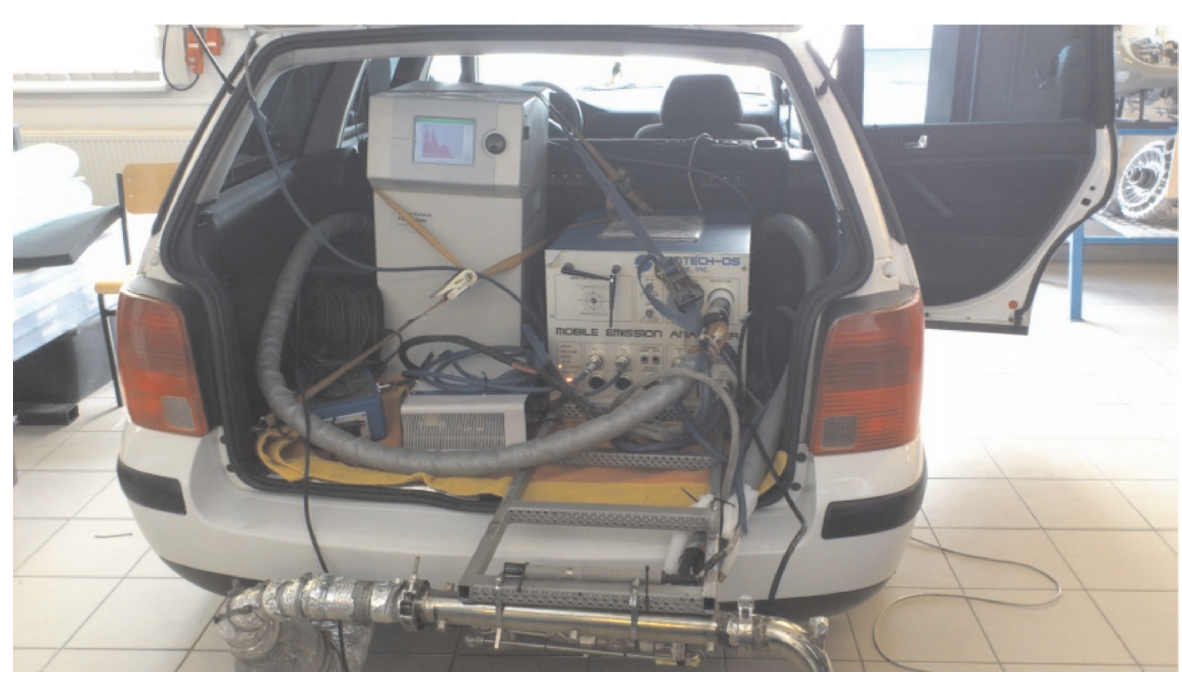

Fig. 3. PEMS measuring equipment during installation inside the vehicle Rys. 3. Aparatura pomiarowa typu PEMS $w$ trakcie montażu w pojeździe

W odniesieniu do przedmiotowych badań wykorzystano analizator SEMTECH-DS firmy Sensors Inc. (Sensors EMission TECHnology; rys. 3). Elementami składowymi opisywanej aparatury badawczej są przede wszystkim odpowiednie dla danych związków chemicznych analizatory: wykorzystujący promieniowanie podczerwone - NDIR (Non-Dispersive Infrared) i ultrafioletowe - NDUV (Non-Dispersive Ultraviolet) oraz analizator płomieniowo-jonizacyjny - FID (Flame Ionization Detector). Ponadto do głównych elementów budowy urządzenia SEMTECH-DS należą $[3,9]$ :

- przepływomierz spalin, mierzący wydatek spalin dla zmiennych warunków pracy silnika; o różnej średnicy, zależnej od objętości skokowej jednostki napędowej pojazdu,

- moduł pozwalający na rejestrację danych z systemu diagnostyki pokładowej pojazdu OBD (On-Board Diagnostics) - określanie m.in. warunków jazdy i parametrów pracy silnika, 
Table 2. Selected parameters recorded during the road tests

Tabela. 2. Wybrane parametry zarejestrowane $w$ trakcie przejazdów testowych

\begin{tabular}{|c|c|c|c|c|}
\hline \multirow{2}{*}{ Parameter/parametr } & \multicolumn{4}{|c|}{ Driving speed/prędkość jazdy [km/h] } \\
\hline & 70 & 80 & 90 & 100 \\
\hline Engine speed/prędkość obrotowa silnika $[\mathrm{rpm}] /[\mathrm{obr} / \mathrm{min}]$ & 1600 & 1800 & 1950 & 2200 \\
\hline Engine load/obciążenie silnika [\%] & 37.3 & 44.2 & 57.8 & 64.6 \\
\hline Exhaust gas flow/wydatek spalin $[\mathrm{kg} / \mathrm{h}]$ & 91.3 & 110.7 & 135.7 & 160.4 \\
\hline Exhaust gas temperature/temperatura spalin $\left[{ }^{\circ} \mathrm{C}\right]$ & 109.1 & 119.5 & 125.1 & 134.3 \\
\hline
\end{tabular}

gas (mass flow meter), which is necessary to calculate the emissions of the individual components (road emissions).

The values of the concentrations of the individual exhaust components were obtained following tests under actual traffic conditions on the test routes in the Poznan area. The test route (a portion of the A2 motorway) has been presented in Fig. 4. Its length was approximately $10 \mathrm{~km}$. The test runs were realized in the afternoon, when the traffic congestion was relatively high. In order to perform the analysis, the vehicle operated at the following speeds: $70,80,90$ and $100 \mathrm{~km} / \mathrm{h}$ (each time the highest $5^{\text {th }}$ gear was engaged).

Table 2 contains several important parameters of the engine for information purposes. The most important in
- moduł umożliwiający komunikację z systemem lokalizacji GPS.

Opisywana mobilna aparatura pomiarowa typu PEMS, oprócz pomiaru stężenia poszczególnych gazowych substancji szkodliwych w spalinach, umożliwia również pomiar masowego natężenia przepływu spalin (przepływomierz), co jest niezbędne do obliczania emisji tych związków - np. emisji drogowej.

Wartości stężeń poszczególnych szkodliwych gazowych składników w spalinach uzyskano w efekcie wykonania badań w rzeczywistych warunkach ruchu podczas przejazdów w rejonie Poznania. Przebieg trasy badawczej, będącej fragmentem płatnej autostrady A2, zaprezentowano na rys. 4. Jej a)

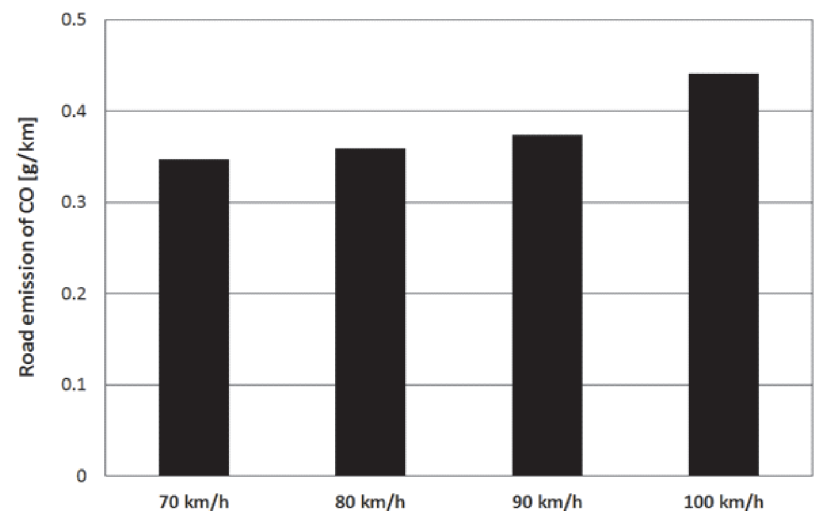

c)

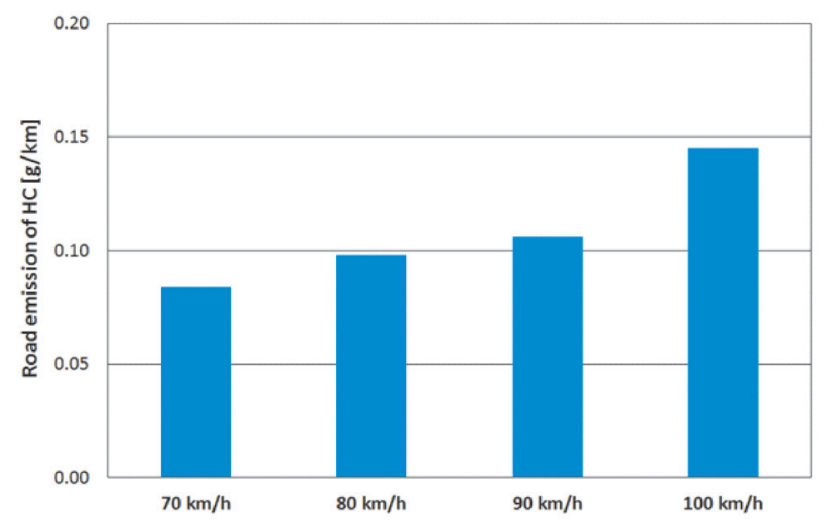

b)

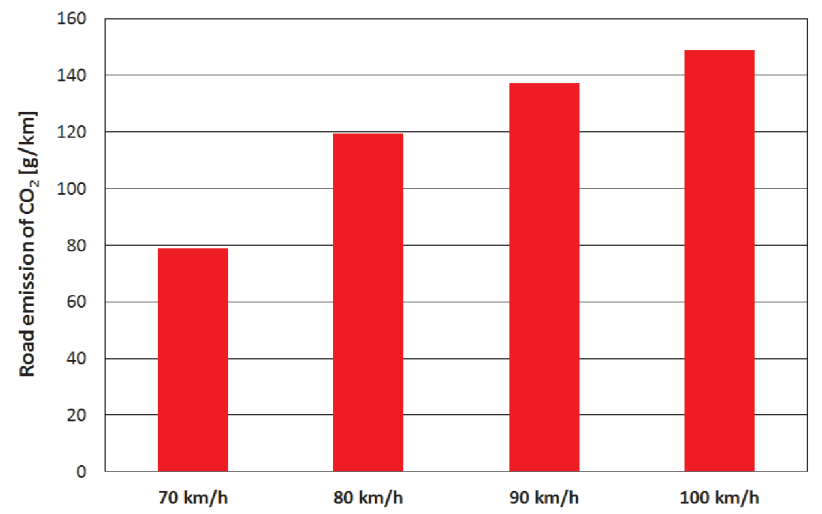

d)

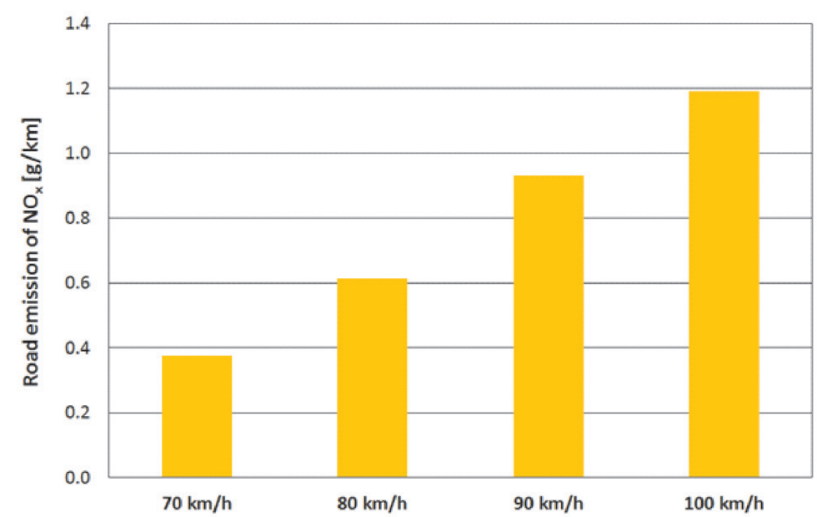

Fig. 5. Road emissions for each driving speed: a) carbon monoxide, b) carbon dioxide, c) hydrocarbons, d) nitric oxides Rys. 5. Wartości emisji drogowej uzyskane dla poszczególnej prędkości jazdy: a) tlenku węgla, b) dwutlenku węgla, c) węglowodorów, d) tlenków azotu 
terms of the exhaust emissions and fuel consumption are the following parameters: engine load, exhaust flow. It is noteworthy that the test runs were initiated at the engine coolant temperature of over $85^{\circ} \mathrm{C}$.

\section{Results of the measurements and analysis}

Based on the calculated accumulated emission of the individual exhaust components (total mass) the on-road emission of these components was calculated (expressed in $\mathrm{g} / \mathrm{km}$ ). The on-road emission was determined for each test run - with the speeds of 70, 80, 90 and $100 \mathrm{~km} / \mathrm{h}$ (Fig. 5 ). The test runs on the selected route in the aspect of the vehicle speed variability are characterized by a clearly varied exhaust emission of $\mathrm{CO}, \mathrm{CO}_{2}, \mathrm{HC}$ and $\mathrm{NO}_{\mathrm{x}}$. When the vehicle drove at the speed of $100 \mathrm{~km} / \mathrm{h}$ the observed relatively high values of the exhaust can be attributed to the increasing influence of the aerodynamic resistance upon exceeding, as we call it, the 'economy speed limit' of $90 \mathrm{~km} / \mathrm{h}$. Observing the value of the on-road emissions of the analyzed exhaust components we may observe that an increase of the driving speed by a mere $10 \mathrm{~km} / \mathrm{h}$ results in an increase in the emission by almost $40 \%$ - as is in the case of the $\mathrm{HC}$ emission (Fig. 5c).

In order to accurately show the differences in the road emission of carbon monoxide, carbon dioxide, hydrocarbons and nitric oxides a relative percentage difference of the emissions was calculated against the reference speed of $90 \mathrm{~km} / \mathrm{h}$ out of the four test speeds. This is presented in Fig. 6. From this figure, it results that for the speed of $70 \mathrm{~km} / \mathrm{h}$ the most noticeable is the reduction of the concentration of $\mathrm{CO}_{2}$ in the exhaust gas (a drop in the emission of this component by over $40 \%$ ) and the reduction of the emission of $\mathrm{NO}_{\mathrm{x}}-$ by almost $60 \%$. For the speed of $\mathrm{V}=100 \mathrm{~km} / \mathrm{h}$ we can clearly see an increase in the emission of hydrocarbons. As said before, the increase amounts to approximately $40 \%$.

Based on the determined on-road emissions the authors have calculated the gas mileage of the vehicle with the długość wynosiła w przybliżeniu $10 \mathrm{~km}$. Przejazdy testowe realizowano w porze popołudniowej, przy występowaniu dość dużego natężenia ruchu na odcinku pomiarowym. W celu przeprowadzenia przedmiotowej analizy uzyskiwano samochodem badawczym prędkość wynoszącą kolejno 70, 80, 90 i $100 \mathrm{~km} / \mathrm{h}$ (każdorazowo przy włączonym najwyższym, 5. biegu).

W tabeli 2 zestawiono informacyjnie kilka istotnych parametrów eksploatacyjnych silnika spalinowego. Na szczególną uwagę, z punktu widzenia emisji związków szkodliwych spalin i zużycia paliwa przez pojazd, zasługują takie parametry, jak: obciążenie silnika oraz wydatek spalin. Należy zaznaczyć, iż pomiary w rzeczywistych warunkach eksploatacji rozpoczynano, gdy temperatura cieczy chłodzącej jednostki napędowej pojazdu badawczego wynosiła ponad $85^{\circ} \mathrm{C}$.

\section{Wyniki pomiarów i ich analiza}

Na podstawie obliczonej skumulowanej emisji poszczególnych substancji szkodliwych w spalinach - masy całkowitej - obliczono w dalszej kolejności emisję drogową tych substancji (określaną w g/km). Emisję drogową określono dla każdego przejazdu - z prędkością 70, 80, 90 i $100 \mathrm{~km} / \mathrm{h}$ (rys. 5). Przejazdy trasy badawczej w zakresie zmienności prędkości jazdy samochodem cechują się wyraźnie odmienną wartością emisji szkodliwych składników spalin w postaci $\mathrm{CO}, \mathrm{CO}_{2}, \mathrm{HC}$ i NO . Przy poruszaniu się obiektu badawczego z prędkością $100 \mathrm{~km} / \mathrm{h}$ obserwowane stosunkowo duże wartości emisji wszystkich substancji szkodliwych wynikają ze znacznie zwiększającego się oddziaływania oporu aerodynamicznego na jadący pojazd po przekroczeniu (przyjętej powszechnie jako tzw. ekonomicznej) prędkości $90 \mathrm{~km} / \mathrm{h}$. Obserwując wartości emisji drogowej analizowanych związków spalin, można zauważyć, iż wzrost prędkości jazdy o zaledwie $10 \mathrm{~km} / \mathrm{h}$ skutkuje zwiększeniem się tej emisji nawet o prawie $40 \%$ - jak dla emisji węglowodorów (rys. 5c).

W celu wykazania dokładnych różnic w emisji drogowej tlenku i dwutlenku węgla, węglowodorów oraz tlenków azotu obliczono względną różnicę procentową emisji wobec stosowanej „porównawczej”, spośród czterech analizowanych prędkości jazdy - 90 $\mathrm{km} / \mathrm{h}$. W formie zbiorczej zaprezentowano to na rys. $6 . \mathrm{Z}$ zestawienia wynika, że najbardziej zauważalna, dla jazdy z prędkością $70 \mathrm{~km} / \mathrm{h}$, jest redukcja zawartości $\mathrm{CO}_{2} \mathrm{w}$ spalinach (spadek wartości emisji o ponad 40\%) oraz redukcja emisji $\mathrm{NO}_{\mathrm{x}}$ - zmniejszenie o prawie $60 \%$. Natomiast dla $\mathrm{V}=$ $100 \mathrm{~km} / \mathrm{h}$ najwyraźniej uwidoczniony jest wzrost wartości emisji drogowej węglowodorów. Jak już wspomniano, zwiększenie emisji węglowodorów wynosi wtedy około $40 \%$.

$\mathrm{Na}$ podstawie określonej emisji drogowej substancji szkodliwych obliczono, przy wykorzystaniu metody bilansu masy węgla, przebiegowe zu- 


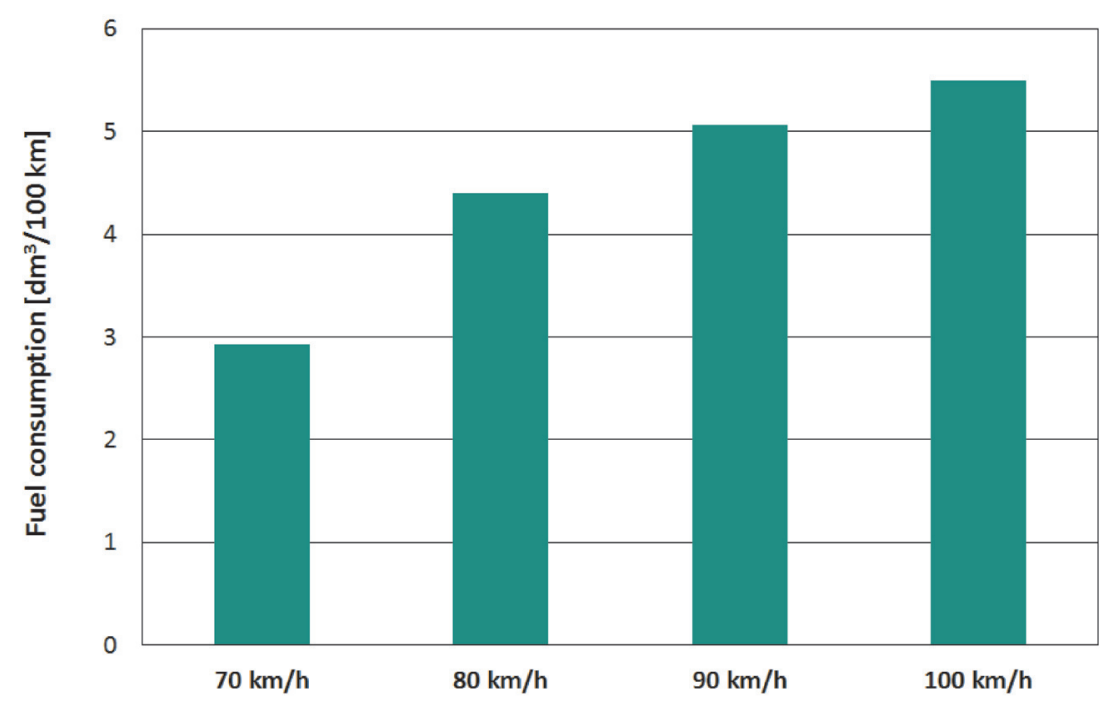

Fig. 7. Fuel consumption for different driving speeds

Rys. 7. Wartość przebiegowego zużycia paliwa określona dla różnej prędkości jazdy życie paliwa przez badany pojazd (rys. 7). Podobnie jak w odniesieniu do emisji drogowej obserwuje się znaczący wzrost wartości zużywanego przez pojazd paliwa na każde przejechane $100 \mathrm{~km}(\mathrm{w}$ zależności od stosowanej maksymalnej prędkości jazdy). Analiza różnic procentowych w obliczonych wartościach przebiegowego zużycia paliwa dla badanego pojazdu typu PC (rys. 8) wskazuje na ponad 40-procentowe mniejsze zużycie paliwa przy jeździe z prędkością 70 $\mathrm{km} / \mathrm{h}$ (wobec $90 \mathrm{~km} / \mathrm{h}$ ) oraz na prawie 10-procentowy wzrost $\mathrm{w}$ wyniku jazdy z prędkością $100 \mathrm{~km} / \mathrm{h}$.

\section{Podsumowanie}

Wykonane badania drogowe samochodu osobowego w rzeczywistych warunkach jego eksploatacji uwidoczniły

carbon balance method (Fig. 7). Similarly to the on-road emission, a significant growth of the amount of consumed fuel was observed for each $100 \mathrm{~km}$ (depending on the applied maximum vehicle speed). The analysis of the percentage differences in the calculated values of the gas mileage for a given PC vehicle (Fig. 8) indicates over $40 \%$ lower fuel consumption at the speed of $70 \mathrm{~km} / \mathrm{h}$ (against the reference speed of $90 \mathrm{~km} / \mathrm{h}$ ) and almost a 10 time increase in the fuel consumption at the speed of $100 \mathrm{~km} / \mathrm{h}$.

\section{Conclusions}

The tests of the passenger vehicle performed under actual traffic conditions have shown a significant influence of the vehicle speed on its exhaust emissions. A much lower on-road emissions were observed

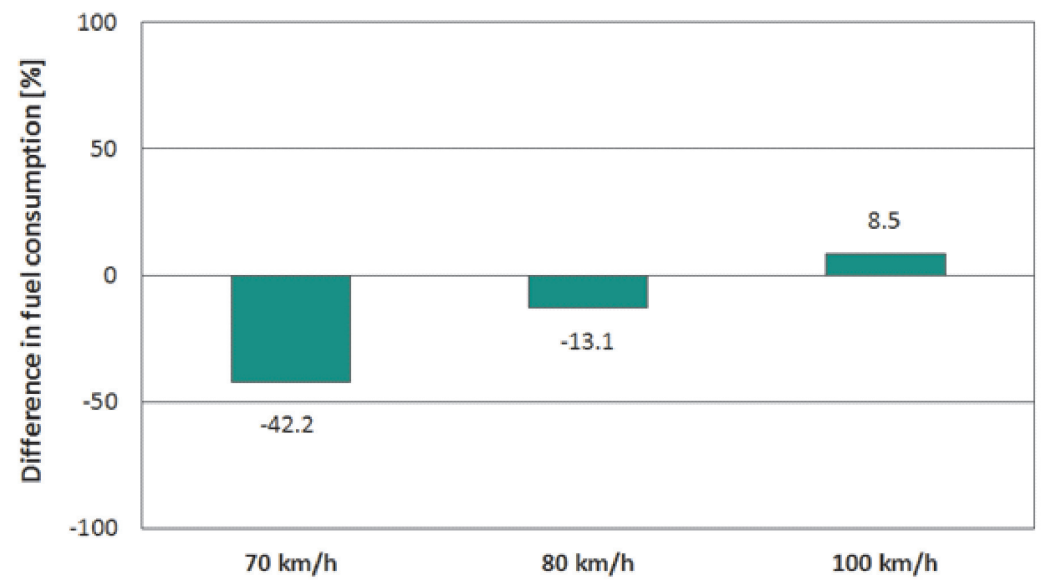
for the speed of $\mathrm{V}=70 \mathrm{~km} / \mathrm{h}$ (against the reference speed of $90 \mathrm{~km} / \mathrm{h}$ ) and much higher - when the vehicle drove at the speed of $\mathrm{V}=100 \mathrm{~km} / \mathrm{h}$. It is very often observed that the road speed limits are frequently exceeded by the drivers. Bearing in mind the conclusions of the authors drawn from the performed investigations, we should note that failing to adhere to the traffic regulations could significantly impact the natural environment including humans. It is thus strongly advisable to rationalize the vehicle operation (vehicle speed).

These were preliminary tests. In order to fully determine the influence of the vehicle speed on its ecological performance the tests need to be continued and extended. The trend in further research will be exhaust emissions tests carried out on a larger group of vehicles (including gasoline engines and engine fueled with alternative fuels: LPG

znaczący wpływ osiąganej prędkości jazdy na emisję gazowych substancji w spalinach. Należy wskazać na znacząco mniejszą emisję drogową tych związków przy jeździe z V= $70 \mathrm{~km} / \mathrm{h}$ (wobec prędkości $90 \mathrm{~km} / \mathrm{h}$ ) oraz znaczący wzrost wartości emisji przy samochodzie poruszającym się z V = $100 \mathrm{~km} / \mathrm{h}$. Na drogach dość często można zaobserwować stosowanie przez kierowców nadmiernej prędkości jazdy. Mając na uwadze wnioski wyciągnięte z przeprowadzonych badań, warto podkreślić, że może to w dużym stopniu wpływać na środowisko naturalne i człowieka. Trzeba więc racjonalnie podchodzić do sposobu eksploatacji (prędkość jazdy) wszelkich pojazdów.

Wykonane badania były badaniami wstępnymi. Aby pełniej określić wpływ prędkości jazdy samochodem na właściwości ekologiczne pojazdu należy poszerzyć badania. 
and $\mathrm{CNG}$ ) as well as vehicles of different homologation categories: Light Duty-Vehicles (LDV) and Heavy-Duty Vehicles (HDV).
Kierunkiem dalszych prac będzie między innymi przeprowadzenie badań toksyczności spalin większej liczby pojazdów (również z silnikami o zapłonie iskrowym i zasilanych różnymi paliwami: LPG oraz CNG), w tym pojazdów innych kategorii homologacyjnych typu: LDV (Light Duty Vehicle - lekki pojazd użytkowy) i HDV (Heavy Duty Vehicle pojazd ciężarowy).

\section{Bibliography/Literatura}

[1] Daham B., Li H., Andrews G.E., Ropkins K., Tate J.E., Bell M.C.: Comparison of real world emissions in urban driving for Euro 1-4 vehicles using a PEMS. SAE Technical Paper Series 2009-01-0941.

[2] Engeljehringer K.: Automotive emission testing and certification. Past, present and future. $2^{\text {nd }}$ International Exhaust Emissions Symposium, Bielsko-Biała 2011.

[3] Merkisz J., Pielecha J., Radzimirski S.: Emisja zanieczyszczeń motoryzacyjnych w świetle nowych przepisów Unii Europejskiej. Wydawnictwa Komunikacji i Łączności, Warszawa 2012.

[4] Piechna J.: Podstawy aerodynamiki pojazdów. Wydawnictwa Komunikacji i Łączności, Warszawa 2000.

[5] Toy E.: The distribution of vehicle mass in the on-road fleet of passenger vehicles. SAE Technical Paper Series 2004-01-1161.

[6] Vermeulen R.J.: The effects of a range of measures to reduce the tail pipe emissions and/or the fuel consumption of modern passenger cars on petrol and diesel. TNO report, IS-RPT-033DTS-2006-01695.

[7] Walsh M.: Global trends in motor vehicle pollution control: a 2011 update. Part 3. Combustion Engines, No. 4/2011 (147), pp. 98-103.

[8] http://autowiedza.republika.pl/opory_ruchu.html (dostęp z dnia 15.07.13)

[9] http://www.sensors-inc.com

Prof. Marianna Jacyna, DSc., DEng. - Professor in the Faculty of Transport at Warsaw University of Technology.

Prof. Marianna Jacyna - profesor na Wydziale Transportu Politechniki Warszawskiej

e-mail:maja@wt.pw.edu.pl

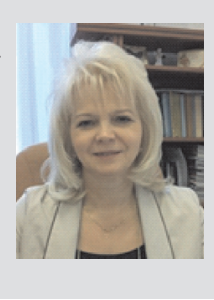

Prof. Agnieszka Merkisz-Guranowska, DSc.- Professor in the Faculty of Machines and Transport at Poznan University of Technology.

Dr hab. Agnieszka Merkisz-Guranowska, prof. PP - profesor na Wydziale Maszyn Roboczych i Transportu Politechniki Poznańskiej.

e-mail: agnieszka.merkisz-guranowska@put.poznan.pl

\section{Nomenclature/Skróty i oznaczenia}

CI Compression Ignition/silnik o zapłonie samoczynnym (ZS)

CNG Compressed Natural Gas/sprężony gaz ziemny

DOC Diesel Oxidation Catalyst/utleniajacy reaktor katalityczny dla silników ZS

DPF Diesel Particulate Filter/filtr cząstek statych

FID Flame Ionization Detector/analizator płomieniowo-jonizacyjny

GPS Global Positioning System/system nawigacji satelitarnej

HDV Heavy-Duty Vehicle/pojazd ciężarowy

LDV Light-Duty Vehicle/lekki pojazd użytkowy

LPG Liquefied Petroleum Gas/gaz ptynny, mieszanina propanu i butanu

NDIR Non-Dispersive Infrared/analizator niedyspersyjny na podczerwień

NDUV Non-Dispersive Ultraviolet/analizator niedyspersyjny na promieniowanie ultrafioletowe

OBD On-Board Diagnostics/system diagnostyki pokładowej pojazdu

PC Passenger Car/samochód osobowy

PEMS Portable Emissions Measurement System/aparatura mobilna do badań toksyczności spalin

Prof. Jerzy Merkisz, DSc., DEng. - Professor in the Faculty of Machines and Transport at Poznan University of Technology.

Prof. Jerzy Merkisz - profesor na Wydziale Maszyn Roboczych i Transportu Politechniki Poznańskiej. e-mail: jerzy.merkisz@put.poznan.pl

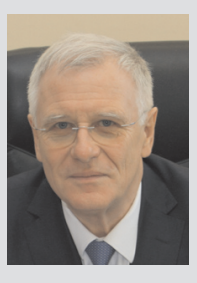

Jacek Pielecha, DSc. DEng. - doctor in the Faculty of Machines and Transport at Poznan University of Technology.

Dr hab. inż. Jacek Pielecha - adiunkt na Wydziale Maszyn Roboczych i Transportu Politechniki Poznańskiej.

e-mail: jacek.pielecha@put.poznan.pl

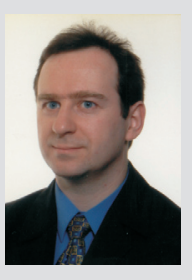

Maciej Andrzejewski, DEng. - senior assistant in the Rail Vehicles Institute "TABOR" in Poznan.

Dr inż. Maciej Andrzejewski - starszy asystent w Instytucie Pojazdów Szynowych "TABOR" w Poznaniu.

e-mail:maciej_andrzejewski@op.pl

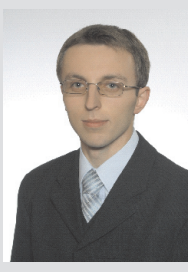

